\title{
8 \\ High-resolution lidar analysis of the Fisi Tea defensive earthwork at Lapaha, Kingdom of Tonga
}

\author{
Phillip Parton, Geoffrey Clark and Christian Reepmeyer
}

\section{Introduction}

In many prehistoric societies, earthwork defences were among the costliest and largest built structures and required a significant investment in resources, particularly labour, land and materials. Consequently, the construction of major defences was not undertaken lightly and they were frequently built in response to an imminent threat of intense violence (Keeley 1996). Earthwork defences often enclosed residential communities and elite centres, whereas others were larger and included hinterlands and appear to have defended a regional area (Connah 2000; Fox 1976; Scherer and Golden 2006; Webster et al. 2007). In both cases, defences protected the areas most important to the community and represent emic statements of group territory (Webster et al. 2008:349).

Long defensive systems and 'great walls' that protect settlements and their hinterlands have been something of a puzzle to archaeologists (Arkush and Stanish 2005:10). While the perceived logistical challenge of occupying long defensive systems may be the primary source of confusion, traditional archaeological and survey methodologies often limit the amount of spatial data that can be gathered. Long defensive systems require considerable resources to map and to record in detail the various defensive elaborations, in addition to the regional geography of the areas on both side of the defences.

Remote sensing technologies, in particular lidar, have potential to provide the high-resolution data necessary to analyse earthworks at both local and landscape levels. The adoption of lidar technology by archaeologists for site prospection has been swift and profound, and has been likened to a 'paradigm shift' by some (Chase et al. 2012). Despite calls for archaeologists to better engage with the full value of lidar data (Opitz et al. 2015), applications beyond site prospection are still limited (Hannon et al. 2017; Lustig et al. 2018).

The high accuracy and vegetation-penetrating properties that make lidar so useful for site prospection also allow lidar to be used in lieu of traditional archaeological and survey methodologies. Lidar is particularly well suited to the analysis of structurally simple monumental earthworks such as ditches, ramparts, mounds and quarries/excavations. However, when using 
lidar data, it is important to understand the sources of error present in the survey system and to implement a methodology to evaluate measurement error throughout an analysis to ensure that results are accurate and defensible.

In this chapter, lidar data are analysed to examine a large and newly reported earthwork defending the elite centre of Lapaha and eastern hinterlands on the island of Tongatapu in the Kingdom of Tonga. The analysis demonstrates how a thorough investigation of lidar datasets, in conjunction with targeted field excavations, contributes new knowledge about the earthwork-including its defensive features and method of construction - and inferences about labour organisation and workforce size. In addition, our study suggests that Fisi Tea represents a schism between two or more groups on Tongatapu at the time it was built that is only hinted at in traditional history. The age and location of the defensive boundary highlights the key role that warfare played in the development of Tonga's prehistoric political system, arguably one of the few archaic states to develop in Oceania.

\section{Materials and methods}

\section{Site description}

The island of Tongatapu is the largest in the Tongan archipelago and is the location of the presentday capital of Nuku'alofa. Prior to the establishment of the nation state of Tonga in the nineteenth century, Tongatapu was also the seat of power of the paramount chiefly lineage known as the $\mathrm{Tu}$ ' $\mathrm{i}$ Tonga, who was a descendant of the god Tangaloa Eitumatāpu'a. The influence of the Tu'i Tonga chiefly system extended to eastern Fiji, 'Uvea and Samoa in addition to the Tongan archipelago c. 1200-1800 CE. Monumental architecture is associated with the principal places of the Tu' $\mathrm{i}$ Tonga, first at Heketā in the north-east of Tongatapu (1200-1300 CE), and shortly after at Lapaha some $8 \mathrm{~km}$ south-west of Heketā, on the sheltered shores of the Fanga 'Uta lagoon (Clark and Reepmeyer 2014). Lapaha is remarkable in Tonga as the site of the monumental tombs of the Tu'i Tonga as well as other large engineering projects such as a c. 20 ha area of reclaimed land, wharf infrastructure, and a series of fortifications that enclosed the administrative and religious core of the ancient Tongan state (Figure 8.1) (Clark et al. 2008).

The fortification of Fisi Tea (Figure 8.1) was first identified by Parton et al. (2018) in an inventory of defensive sites on Tongatapu located with lidar. Defensive sites on Tongatapu are predominantly ring-ditch fortifications enclosing areas of up $315000 \mathrm{~m}^{2}$, but more commonly are between $10000 \mathrm{~m}^{2}$ and $50000 \mathrm{~m}^{2}$. The inventory also identified a subset of defensive earthworks termed linear fortifications with different characteristics from enclosure fortifications. Linear fortifications often begin at natural barriers/terrain edges and appear to have been regionally focused compared with enclosed fortifications that protected community groups. Of the seven linear fortifications identified with lidar, Fisi Tea was the most enigmatic due to its imposing dimensions and association with the Tu'i Tonga centre at Lapaha. We examined Fisi Tea through an analysis of lidar data, archaeological investigation, radiocarbon dating and traditional history. 


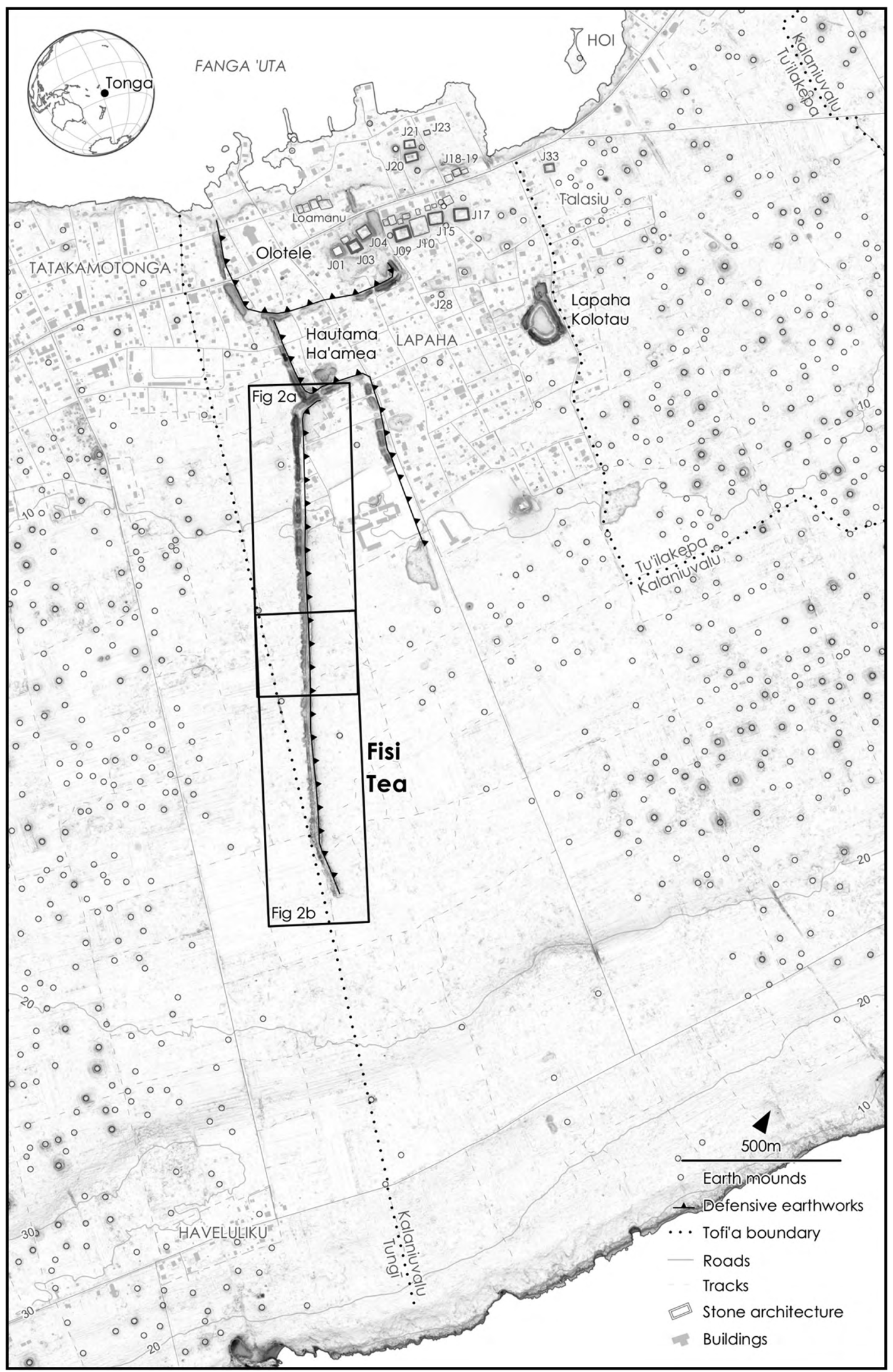

Figure 8.1. Map of Lapaha and hinterlands with location of Fisi Tea and other defensive earthworks highlighted.

Source: Phillip Parton, Geoffrey Clark and Christian Reepmeyer. 


\section{Lidar data}

Aerial topographic lidar and aerial photography were acquired by the Tongan Government as a component of the AusAid (currently Australian Aid) funded Pacific Adaptation Strategies Assistance Program over the islands of Tongatapu, Lifuka and Foa to inform coastal and planning management and climate change. The lidar was captured on six flights carried out from 3 to 24 October 2011 with 104 runs, and eight cross runs flown at $750 \mathrm{~m}$ above ground level. The Optech ALTM-Orion sensor collected four discrete returns and intensity. The swath width of the lidar was $578 \mathrm{~m}$ and overlap between flight lines was 20 per cent. The project was designed to meet project specifications of $4 \mathrm{pt} / \mathrm{m}^{2}$; however, post survey checks indicate that $7.87 \mathrm{pt} / \mathrm{m}^{2}$ was achieved with all returns and a $5.67 \mathrm{pt} / \mathrm{m}^{2}$ density with only first returns (a pseudo pulse density). The survey was conducted on the WGS84 horizontal datum and projected to the Tonga Map Grid 2005. Vertical datum for the survey was the EGM2008 geoid and a local adjustment of $0.77 \mathrm{~m}$ was made by the contractor to adjust the vertical datum of the project to mean sea level at the benchmark TON1 as set by the 'Nuku'alofa SEAFRAME tide gauge. The GPS base station was located at the Fua'amotu International Airport and the entirety of the survey area was within $50 \mathrm{~km}$ of the base station (Anderson 2011).

Raw laser data was classified by the contractor into ground or non-ground classifications, according to the Intergovernmental Committee on Surveying and Mapping (ICSM) Classification Level 2 Ground Surface Improvement standards. Independent survey checks indicate that the vertical accuracy of the project in Tongatapu is $0.15 \mathrm{~m}$ at 95 per cent confidence level. The density of points classified as 'ground' was calculated at $1.04 \mathrm{pt} / \mathrm{m}^{2}$. Point cloud data was stored in the binary LAS format where derivative products, such as digital elevation models (DEM), intensity imagery and foliage models, were created by the contractor and delivered to the Tongan Government. Approval to use the lidar dataset for archaeological research was granted to the authors by the Tongan Government and Geosciences Australia.

\section{Sources of lidar error}

Error is inherent in all measurement systems. If we are to unlock the potential of lidar as a survey tool to investigate prehistoric earthworks, the sources of lidar error need to be understood and quantified, and propagated through an analysis so that reliable results are obtained (see Fernandez-Diaz et al. 2014 for description of components of lidar for archaeologists). Error in lidar is complex, but sources can be summarised as coming from positioning and altitude of the aircraft, sensor errors, and point cloud classification errors (Hodgson and Bresnahan 2004:333). These sources of error can be minimised thorough survey design, and although archaeologists may have little control over the survey design, awareness of error sources is important for understanding measurement accuracy.

\section{Lidar manipulation}

\section{DEM creation}

A primary deliverable from the contractor were pre-processed raster DEMs. Survey documentation describing the processing methodologies to create the DEMs from the point cloud data was not sufficient to recreate the methodology. This is important as different methods of point cloud rasterisation propagate error in different ways (Hartzell et al. 2015:1150-1151). Point clouds were rasterised using a binning approach, where elevation points are placed into raster bins (or cells) and a single elevation value is returned for each bin by averaging all the points that fall within the raster bin. The binning approach was used as it simplifies the propagation of error through to the final volume determinations. 


\section{DEM error}

Modelling of error in the lidar elevation model follows the methodology of Hodgson and Bresnahan (2004), where a reference dataset collected from a source of higher accuracy is compared to the elevation model and a root mean square (RMS) value calculated. Different types of vegetation cover affect the accuracy of ground point determination and subsequent DEM creation, therefore error needed to be calculated and applied based on vegetation type. Because the lidar dataset is being reprocessed several years after initial capture, it was difficult to identify with confidence vegetation types based on the supplied information, therefore reference data was amalgamated into two vegetation types: 'trees' and 'long grass', capturing the main variation in vegetation on Tongatapu. An additional category of 'bare earth' includes areas with little or no vegetation cover. RMS was calculated for each of the vegetation types (Table 8.1).

It should be noted that the check measurements also contain error, and ideally these errors too would be propagated through the calculations. The survey report did not contain information on how these points were acquired so it is not possible to account for these errors. In practice, these errors are likely to be very small and contribute minimally to the overall error budget.

Vegetation cover was mapped by combining the supplied canopy height model (CHM) and foliage cover model (FCM). The CHM measures the height of the canopy above ground surface whereas the FCM measures foliage density. While not a rigorous vegetation classification, an overall accuracy of 91 per cent (Table 8.2) following evaluation and the results of the classification were suitable for assigning error to different vegetation types (Congalton and Green 2009:57).

Table 8.1. Root mean square (RMS) values calculated per vegetation type used in error analysis.

\begin{tabular}{|l|c|c|}
\hline Vegetation type & Number of points in class & RMS (mm) \\
\hline Trees & 92 & 0.094 \\
\hline Long grass & 54 & 0.175 \\
\hline Bare earth & 1128 & 0.061 \\
\hline
\end{tabular}

Source: Authors' data.

Table 8.2. Error matrix and accuracy assessment of vegetation classification for determination of digital elevation model (DEM) error zones.

\begin{tabular}{|l|l|c|c|c|c|}
\hline & & \multicolumn{3}{|c|}{ Reference data } & \multirow{2}{*}{ Row total } \\
\hline \multirow{3}{*}{ Classified data } & & $\mathbf{1}$ & $\mathbf{2}$ & $\mathbf{3}$ & \\
\cline { 2 - 6 } & 1 & 1042 & 3 & 7 & 1052 \\
\cline { 2 - 6 } & 2 & 78 & 46 & 19 & 143 \\
\cline { 2 - 6 } & 3 & 8 & 5 & 66 & 79 \\
\hline & Column total & 1128 & 54 & 92 & 1274 \\
\hline
\end{tabular}

\begin{tabular}{|l|l|}
\hline \multicolumn{2}{|l|}{ Overall accuracy $=\mathbf{9 1} \%$} \\
\hline Producer's accuracy & User's accuracy \\
\hline $1=92 \%$ & $1=99 \%$ \\
\hline $2=85 \%$ & $2=32 \%$ \\
\hline $3=71 \%$ & $3=84 \%$ \\
\hline
\end{tabular}

$1=$ bare earth, 2 = long grass and $3=$ trees. Producer accuracy describes the accuracy of the classifier to correctly place the reference data in the right class, and User accuracy describes the reliability of each class. Source: Authors' data. 


\section{Calculation of earthwork volumes}

The volume under the binned raster surface can be defined mathematically as:

$V=A \sum_{i=1}^{n} z_{i}$

Where $A$ is the size of the raster bins used to create the DEM and $z$ is the binned elevation value.

The global propagation of variance (GLOPOV) (Ghilani 2010) defines the variance of the volume under the binned raster surface:

$\sigma_{V}^{2}=A^{2} \sum_{i=1}^{n} z_{i}^{2}$

Finally, to calculate the volume of the earthwork, the DEM is subtracted from a DEM without the earthwork. Variance of the volume of the earthwork is defined as:

$\sigma_{V_{\text {earth work }}}^{2}=\sigma_{V_{\text {with earth work }}}^{2}+\sigma_{V_{\text {without earth work }}^{2}}$

\section{Creation of pre-earthworks DEM}

To create a surface showing the original ground surface before Fisi Tea construction, Fisi Tea needed to be digitally 'erased' from the DEM. Since the construction area of Fisi Tea is well defined by changes in surface slope, a slope threshold of five degrees was applied to define the construction area. The slope threshold raster was then used to mask the construction area and a plane fitting/inverse distance weighting (IDW) interpolation was used in ArcMap to fill the created void. DEM visualisation techniques were applied to the new DEM to highlight boundary or interpolation errors and the slope threshold boundary was manually altered as necessary. The error model of the original DEM was adopted as the error model for the pre-earthworks DEM.

\section{Extraction of morphological attributes}

A series of morphological attributes were extracted from the DEM for survey analysis. The overall limits of Fisi Tea were previously defined by the slope threshold raster, and additional earthwork morphological variables defined include: the centre or highest point of the rampart, the centre or lowest point of the ditch, and the transition between the cut and fill.

The position of the rampart centre was defined by the line of the watershed between the northern and southern parts of the rampart. Hydrology tools in ArcMap were used to identify the watershed and the line extracted. Similarly, the centre of the ditch was defined in the same manner; however, the ditch only becomes the watershed when the DEM is inverted. The $D E M_{\text {inverse }}$ is calculated by: $D E M_{\text {inverse }}=(-1 \times(D E M-M a x H g t))+M i n H g t$

The watershed is then calculated in the same manner and digitised. Finally, the cut/fill transition is defined by calculating the zero elevation contour when the pre-earthworks DEM is subtracted from the DEM including the earthwork.

\section{Creation of analysis units}

To analyse the morphology of Fisi Tea, analysis units in the form of regularly spaced elevation profiles, called chainages, were used. A reference line from which the profiles were based was created as a 'best fit' line separately through the cut/fill transition of both the main length and bend portion of Fisi Tea. Elevation profiles were created at one metre intervals perpendicular to the line of best fit (Figure 8.2). 


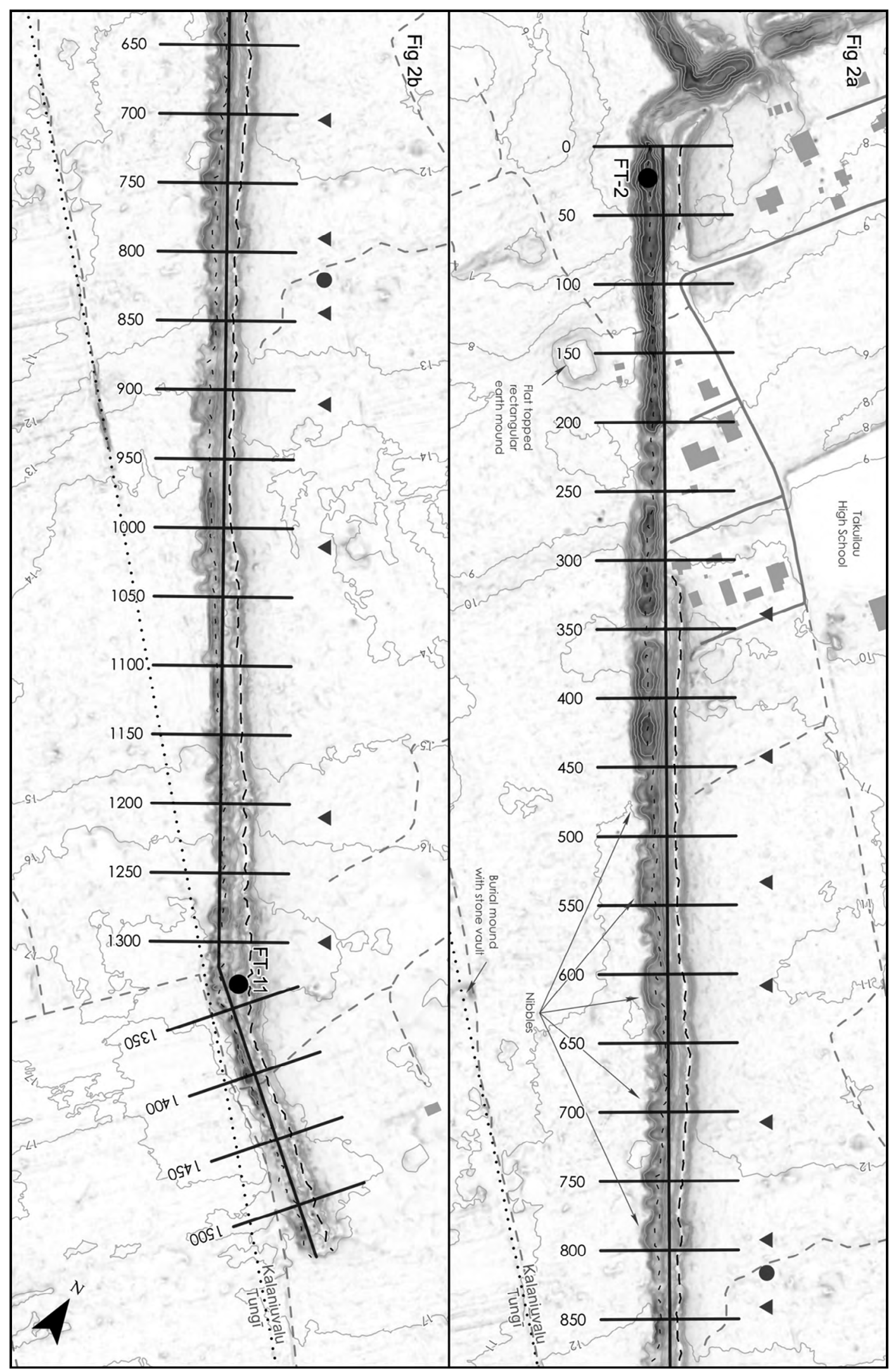

Figure 8.2. Detail of Fisi Tea.

Location of radiocarbon samples highlighted. Triangles are placed at high point lookouts and the circle locates the possible minor gate feature.

Source: Phillip Parton, Geoffrey Clark and Christian Reepmeyer. 


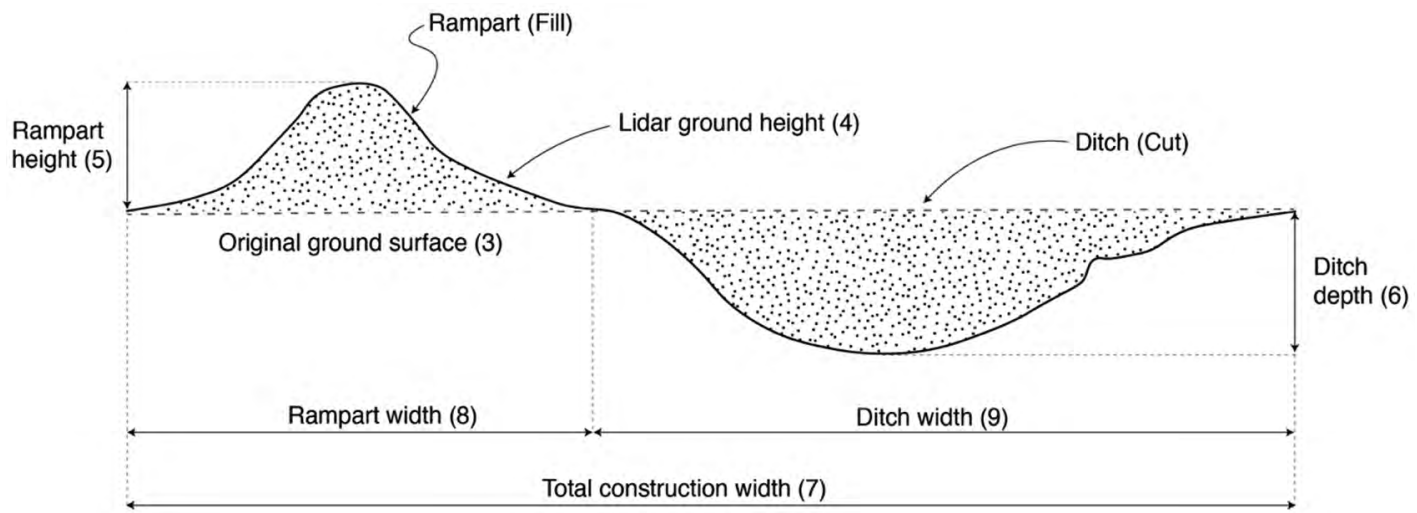

Figure 8.3. Pictorial overview of morphological attributes calculated at each elevation profile.

Source: Phillip Parton, Geoffrey Clark and Christian Reepmeyer.

For each of the elevation profiles, nine attributes were extracted totalling over 474000 individual observations of rampart and ditch morphology. The attributes were: (1) elevation profile chainage; (2) variance; (3) original ground height; (4) lidar ground height; (5) maximum rampart height; (6) maximum ditch depth; (7) total construction width; (8) rampart width and (9) ditch width (Figure 8.3).

The attribute data were exported from ArcMap and were summarised using R scripts (3.5.0) and Tidyverse (1.2.1) packages to group attributes by chainage and calculate cut and fill volumes at each chainage.

\section{Radiocarbon dating Fisi Tea}

Five radiocarbon ages from Fisi Tea were obtained on charcoal samples excavated at two locations. The FT-2 excavation was located in the centre of the ditch toward the start of Fisi Tea to examine the depth of ditch fill from rampart erosion. FT-11 was on the inner (ditch side) of the rampart, inland and near to where the earthwork changes direction (Figure 8.2). Two charcoal samples of unidentified wood charcoal were collected from limestone debris at the ditch base c. $70 \mathrm{~cm}$ below the surface. Ditches are notorious for capturing material unrelated to the age of construction (Bell et al. 1996:79), and unidentified wood charcoal can contain significant in-built age. The FT-2 charcoal samples were discrete charcoal fragments in quarried limestone that may have been deposited during ditch construction, but the charcoal could be from burning old wood. From the FT-11 excavation, three charcoal endocarp samples were collected from the interface between the rampart fill and the buried topsoil horizon (O Horizon). Endocarp has a small amount of in-built age, but carbonised nut shell can exist in upper soils for long periods.

All charcoals were dated with AMS (accelerator mass spectrometry) at the ANU Radiocarbon Laboratory and calibrated with Calib 8.1 using the SHcal13 dataset.

\section{Energetics}

The calculation of energetics estimates the energy and labour investments for earthwork features and the results can encode many of the social decisions made at the time of construction (Clark and Martinsson-Wallin 2007; Kim 2013). Energetics are calculated by accounting for the materials used in the construction of the feature that in the case of Fisi Tea is the volume of the ditch excavation and related volume of the associated rampart 'fill'. 
These volume measurements are converted to labour estimates to determine how long construction activity might have taken using a larger or smaller workforce. The high resolution of lidar-based volume determinations allows accurate and defensible estimates of the amount of energy invested in the construction of large archaeological features that are otherwise difficult to obtain with ground-based mapping techniques.

While the energetics calculations are simple mathematically, the energetics approach is not without its limitations and caveats. Firstly, the presence of a large and monumental scale earthwork does not necessarily indicate social complexity nor the use of corvée labour in construction. If an earthwork is being used to argue for these aspects, then Rosenswig and Burger (2012) argue that they need to be demonstrated by additional lines of evidence. Corvée labour in prehistoric Tonga was called fatongia. Fatongia is defined as: 'a tax, work done for the government; compulsion, necessity' (Rabone 1845:90), and 'a tax, impost' (Martin 1991). A broader definition of fatongia is given by Lātūkefu (1980:65-66), where it forms part of the 'traditional values' of Tongan society consisting of faka'apa'apa (respect), mateaki (loyalty) and fatongia (duty). Lātūkefu expands on the definition of fatongia by describing it as the governing principle of relationships between classes. The chief's fatongia to their people was to protect them, settle disputes and provide them with good living conditions. The fatongia of the people to their chiefs was to give both their labour and the best of their produce and crafts to the chief when called upon through a fono or town meeting. Traditionally, fatongia is linked to the transformations introduced by the chief Lo'au when the kava ceremony was introduced by the tenth Tu'i Tonga, Momo, around 1200 CE (Gifford 1929:131).

Secondly, the interpretation of energetics calculations will be different if the earthwork feature was constructed over a long period of time or in multiple stages (Blitz and Livingood 2004). The proposed defensive function of Fisi Tea makes it unlikely that it was built incrementally over a long period of time due to the imminent threat of intense violence that likely prompted its construction. While differing construction strategies were employed along the length of Fisi Tea, the archaeological data supports the view that Fisi Tea is a single-event construction (see below).

Finally, it is important to note that energetics calculations do not account for the construction of structures built using perishable materials (Kolb 1997). Nineteenth-century fortifications in Tonga were made with palisades on the rampart and included additional elaborations such as fighting stages and observation posts, all of which are unaccounted for in the calculations. Additionally, the calculations do not record the energy invested in the workforce such as in additional food production and tool use and maintenance. For these reasons, the estimates should be treated as conservative 'minimum' values.

Accounts of the digging technology used by Tongans by early European visitors describe the ground being dug 'with an instrument of hardwood, about five feet long, narrow, with sharp edges, and pointed', called huo in Tongan (Anderson in Beaglehole 1967:934; Wilson 1799:245). The description of the huo is similar to those of digging sticks in Mesoamerica and the labour estimates of Erasmus (1965) and Abrams (1989) were therefore used to calculate the amount of labour required to excavate material necessary to construct Fisi Tea $\left(2.6 \mathrm{~m}^{3} /\right.$ day (Abrams 1989:70; Erasmus 1965:285)). Data from Abrams provides the additional information of the labour required to shape and compact the fill layers of the earthwork $\left(4.8 \mathrm{~m}^{3} /\right.$ day (Abrams 1989:70)). The Erasmus values are a widely used standard for labour calculations, allowing crossreferencing to other projects (e.g. Kolb 1997; Ortmann and Kidder 2013; Pickett et al. 2016; Sherwood and Kidder 2011). The figures of Erasmus and Abrams lack standard deviations and a nominal standard deviation of $1 \mathrm{~m}^{3}$ was applied to both the excavation rate and the fill rate. Based on modern field observations, including our observations of manual earth moving in Tonga, these estimates appear to be appropriate. 


\section{Results}

\section{Fisi Tea morphology}

Analysis of rampart and ditch height above and below the original ground surface along the length of Fisi Tea indicate little variation in rampart height. The average height of the rampart was $1.8 \pm 0.4 \mathrm{~m}$. In contrast, ditch depth was more variable, with deeper excavations for approximately the first third of the earthwork and shallower excavations over the remaining two thirds. A large change in depth occurs at c. $\mathrm{CH} 450.00$ with another smaller change at c. $\mathrm{CH} 800.00$. The results match field observations where rampart height appeared consistent whereas ditch depth became shallower as the excavation moved inland from Lapaha (Figure 8.4a).

The cut and fill analysis mirrors that of rampart height. Fill volumes used in rampart construction remain consistent along Fisi Tea and ditch-cut volumes (and ditch depth) are largest to c. $\mathrm{CH} 450.00$, then become smaller, but are variable through to approximately $\mathrm{CH} 800.00$, and then excavation volume decreases toward the inland end of Fisi Tea (Figure 8.4b).

The average width of the Fisi Tea construction limits (ditch and width) was $37 \pm 6 \mathrm{~m}$, with width ranging from $52 \mathrm{~m}$ to $21 \mathrm{~m}$. Average rampart width was $9 \pm 2 \mathrm{~m}$ and again the limited variation of the rampart is notable (Figure 8.4c). Ditch widths begin large and a decrease in ditch width is recorded at $\mathrm{CH} 450.00$. Further changes to the end of Fisi Tea are obscured by highly variable ditch widths that are likely related to the decreasing depth of sediment on the inland slopes of Tongatapu (Gibbs 1976).

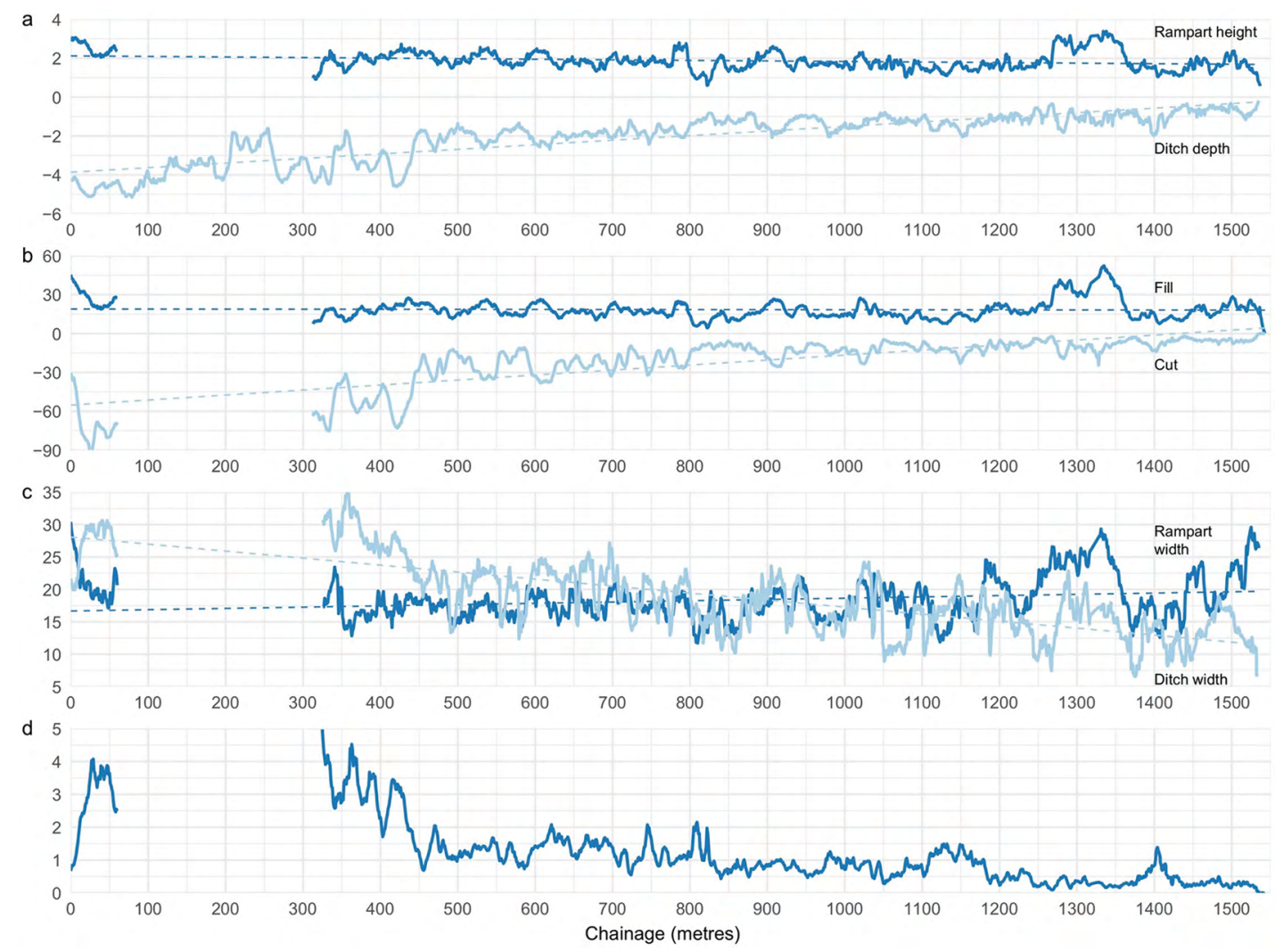

Figure 8.4. Plots of morphological variables.

A. Rampart height and ditch depth above and below original ground surface (metres). B. Cut and fill volumes $\left(\right.$ metres $\left.^{3}\right)$. C. Width of construction limits (metres). D. Cut and fill ratio (unitless).

Source: Phillip Parton, Geoffrey Clark and Christian Reepmeyer. 


\section{Defensive features}

Identifying breaks in the rampart that might be gates is difficult with the current data and no evidence exists for the elaboration of gates such as baffles or screens that are found at some enclosure forts. A small depression in the rampart height data at c. CH825.00 may represent a gate as the rampart is low and the ditch shallow at this location (Figure 8.4a). The location could postdate construction where a section of eroded and slumped rampart was used to make a causeway to cross the ditch. However, either side of the low point are two high rampart points that potentially flanked the defending gate. At the time of the lidar survey in 2011, the area was covered in long grass with no indication of vehicle tracks in the area. In 2018 aerial photography a vehicle track is present. At other fortifications in Tonga, entrance causeways have been adapted to vehicle use. Excavation and additional historical datasets will be necessary to determine whether the location is an original gate and causeway or was formed more recently by vehicle traffic.

A series of regularly spaced high points are visible in the rampart height data (Figure 8.4a). The high points are approximately $1 \mathrm{~m}$ higher than the surrounding rampart and might represent observation or signalling outposts which are critical for the effective use of linear defences (Arkush and Stanish 2005:10). At the bend point of Fisi Tea (Figures 8.1 and 8.2), an enlarged high point, approximately $70 \mathrm{~m}$ long, is present accompanied by significant widening of the rampart. The position close to the end of Fisi Tea appears a likely spot for a major observation or signalling outpost that was built to observe the hinterland. Fully occupying a large linear structure, like Fisi Tea, would require prohibitively high numbers of personnel and signalling or observation outposts are needed for the early identification of an incoming threat and to allow defenders to concentrate forces against attackers along the wall (Connah 2000; LeBlanc 2006).

\section{Volume of Fisi Tea}

The rampart construction attributes observed in the analysis of height, width and volume are strong evidence for the standardisation of the Fisi Tea rampart. Because the rampart construction is relatively uniform, and the destroyed section of rampart (CH61.00-CH313.00) was pushed into the ditch with a bulldozer, it is possible to interpolate the volume of the rampart in this section and to remove it from the ditch to calculate final cut and fill values for the Fisi Tea earthwork. The average rampart volume was used to interpolate the missing values and these values were removed from the excavation volumes to undo the effects of rampart destruction.

The total amount of material used for the construction of the rampart component of Fisi Tea is $28460 \pm 30 \mathrm{~m}^{3}$ and the volume of material excavated for the ditch component is $43330 \pm 42 \mathrm{~m}^{3}$ leaving a total of $14870 \mathrm{~m}^{3}$ of material excess to requirements for rampart construction that was removed from the site. The propagated volume errors are c. 0.1 per cent of the cut and fill volumes, highlighting the high accuracy of lidar-based volume determinations.

\section{Construction sequence}

To investigate the observed changes in rampart/ditch morphology in more detail, the ratio between cut and fill volumes was calculated. Due to the apparent standardisation of the rampart, variation in the cut/fill ratio should largely reflect changes in the excavation strategy. A cut/fill ratio close to 1 indicates that all the material excavated from the ditch was used to construct the immediately adjacent rampart. A ratio larger than 1 indicates that surplus material was excavated and conversely a ratio below 1 indicates the excavation was unable to provide enough material for rampart construction. 
The ratio of cut and fill at Fisi Tea suggests that three possible construction strategies were employed. First, in the locations closest to Lapaha ( $\mathrm{CH} 0.00$ to $\mathrm{CH} 450.00)$, between 2.5 and 4 times more material was excavated from the ditch than was necessary for rampart construction (Figure 8.4d). Field survey indicates that in the lower sections of Fisi Tea, excavation reached into the limestone bedrock while large boulders were left in place. Other early defensive earthworks in Lapaha follow a similar pattern of excessive ditch excavation relative to rampart volume (Olotele 3.1:1, Hautama/Ha'amea 3.6:1, Lapaha Kolotau 2.6:1).

Between CH450.00 and CH825.00 the cut/fill ratio stabilises and varies between 1 and 2 . Field survey through this section showed that excavation into the fractured limestone base ceased and the ditch tracked the bedrock surface. From CH825.00 to the end of Fisi Tea, the cut/ fill ratio rarely exceeds 1 . Ditch depths become shallower while still tracking the top of the limestone bedrock while the soil-clay layers become thinner as elevation increases on Tongatapu (Gibbs 1976).

The decreasing cut/fill ratios highlight the challenges faced by the builders of Fisi Tea as they worked to build a standardised rampart while excavating less and less material from the ditch. During excavation of the rampart in the upper reaches of Fisi Tea, where the ditch depth is only c. $1 \mathrm{~m}$, the rampart contained a thick redeposited topsoil lens (Figures 8.5a and 8.5b). The topsoil sediment is unlikely to derive from the adjacent shallow ditch and the material likely represents non-local procurement from a series of excavation 'nibbles' or small quarries made into the southern edge of the ditch predominantly between $\mathrm{CH} 450.00$ and $\mathrm{CH} 825.00$ (Figure 8.2). Calculation of the volume of material removed from the 'nibble' excavations of the south-eastern bank was calculated as $3900 \mathrm{~m}^{3}$, compared with the total amount of unaccounted rampart material from CH825.00 onwards which is c. $6000 \mathrm{~m}^{3}$. Additional ditch edge nibbling is possible closer to the disturbed rampart area, but the disturbance prohibits the inclusion of these volumes in the calculation. It is feasible that the nibbles were capable of providing enough material to offset the shortfall of material available locally for rampart construction. The extra distance to transport rampart construction material may have increased the costs of Fisi Tea construction such that it was no longer viable to continue to build the defences in the same manner.

As the ditch became shallower it also became less effective as a defensive structure and Keeley et al. (2007:79) suggest a minimum ditch depth of $1 \mathrm{~m}$ or more as necessary to defend against human attackers. Between $\mathrm{CH} 1200.00$ and $\mathrm{CH} 1250.00$ the Fisi Tea ditch crossed this threshold. The combination of an increasingly costly rampart construction and ineffective defensive ditch likely prompted a rethink of how to defend Lapaha and the hinterland. As the earthwork component of the defence concluded, it is possible that the defence continued to the sea as a palisade or similar barrier made from perishable materials. This can be tested by area excavation of the terminal part of Fisi Tea. 

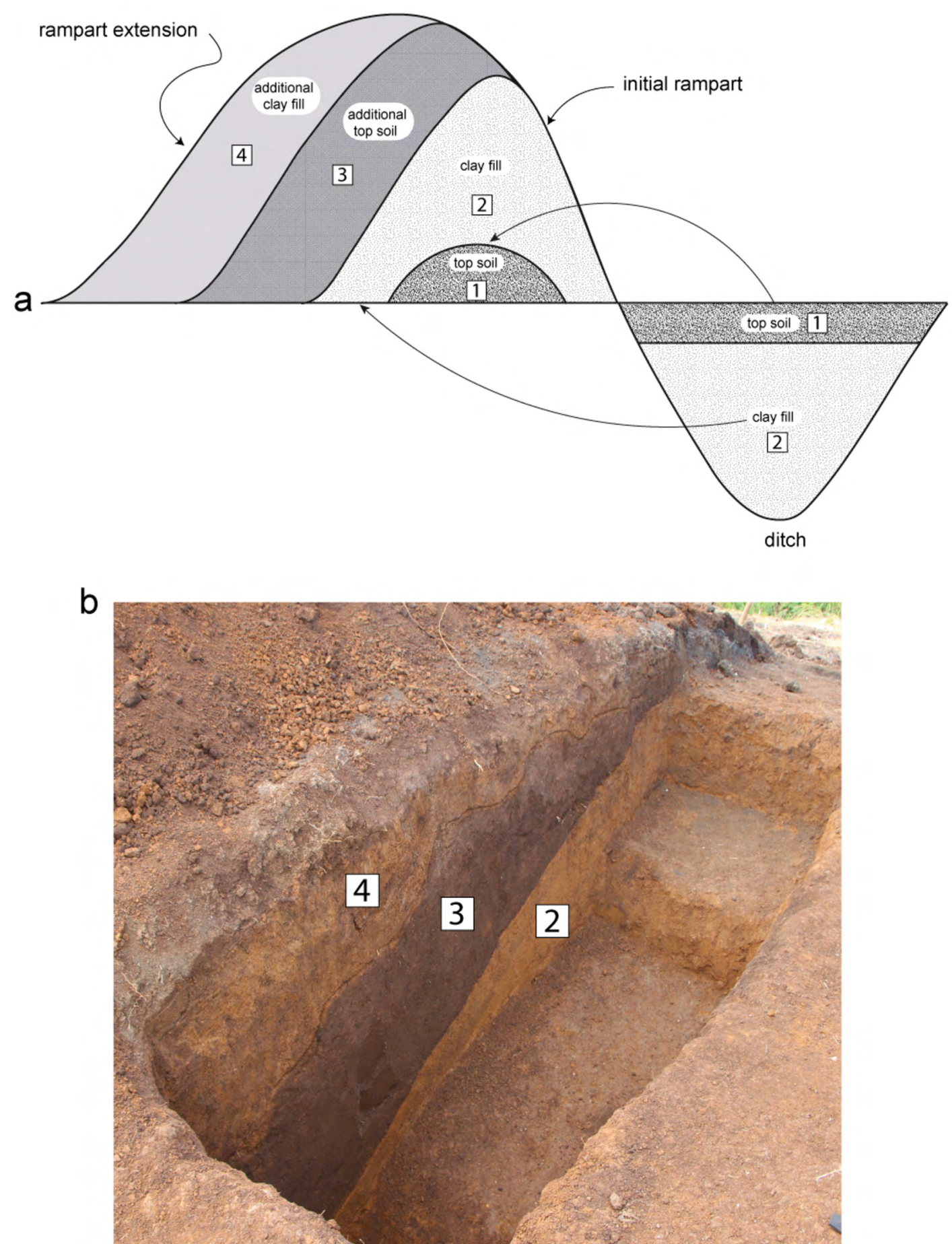

Figure 8.5. Idealised rampart construction sequence.

A. Local topsoil is removed and placed near to the centre of the rampart forming a 'topsoil core' [1]. Local clay fill is removed and the rampart is formed and shaped [2]. If enough local material is available to build the rampart to design then construction continues; otherwise, non-local topsoil is placed on the rampart as quarries for additional material are dug [3]. Non-local clay fill is added to complete the rampart to design [4]. B. Rampart cross-section near to FT-11 excavation showing fill layers 2, 3 and 4 . While fill layer 1 is not shown, fill layer 1 is observed in other rampart excavations where the central core has been penetrated.

Source: Phillip Parton, Geoffrey Clark and Christian Reepmeyer. 


\section{Age of Fisi Tea}

Establishing the age of the Fisi Tea earthwork with radiocarbon is difficult as the concentrated charcoal deposits that are often found beneath the ramparts of enclosed forts were rare, and this paucity has also been noted at other linear defences in Tongatapu that we have examined. At enclosed forts, ditch and rampart construction was preceded by clearing and burning of vegetation presumably to ensure the fortification was of a suitable size to protect a community/ group and the earthworks were properly situated for defence. In addition, some enclosed forts were built in already occupied areas. Ditch construction and deposition of excavated sediment to build a fort rampart frequently protected the rich charcoal deposits left by occupation and vegetation clearance. Linear fortifications are different from enclosed forts in that they appear to mark territory boundaries in the hinterland that were located in zones of low-density occupation, and particular field systems where vegetation clearance and burning was sporadic and charcoal was dispersed rather than concentrated. While all charcoal samples from beneath earthworks are necessarily maximum ages those from linear defences appear most likely to contain environmental charcoal that could significantly pre-date earthwork construction.

Age results from the FT-2 ditch excavation are younger than those from FT-11, which date to 1300-1400 CE when a number of large construction projects were undertaken at Lapaha (Table 8.3) (Clark et al. 2016). There are two reasons for suggesting the endocarp results are too old. First, a relative chronology for the defensive earthworks of Lapaha based on rampart position indicate that the Olotele earthwork near the lagoon was built first, followed by the Ha'amea section, and Fisi Tea was made last. Unpublished ${ }^{14} \mathrm{C}$ ages from Olotele indicate probable construction c. 1400-1500 CE. The two charcoal ages from the FT-2 ditch excavation span 1420-1620 CE and are consistent with the inferred construction sequence compared with the older FT-11 determinations. Second, in Tongan traditions the Olotele fortification was built or rebuilt by the 23rd Tu'i Tonga Takalaua (McKern 1929:93). Allowing a generation interval of 20 and 25 years suggests that Takalaua governed c. 1450-1550 CE and Fisi Tea was likely built c. $1400-1600 \mathrm{CE}$.

Table 8.3. Fisi Tea radiocarbon ages from FT-2 and FT-11 excavations.

\begin{tabular}{|l|l|l|l|l|l|}
\hline $\begin{array}{l}\text { S-ANU } \\
\text { number }\end{array}$ & Context & Sample & CRA & 13C & Calibrated 95.4\% \\
\hline 53907 & FT-2; $75 \mathrm{~cm}$ bs & unidentified wood charcoal & $506 \pm 25$ & -23 & $1420-1460 \mathrm{CE}$ \\
\hline 53909 & FT-2; $76 \mathrm{~cm}$ bs & unidentified wood charcoal & $429 \pm 25$ & -20 & $1450-1620 \mathrm{CE}$ \\
\hline 53825 & FT-11; $120 \mathrm{~cm}$ bs & nut endocarp & $656 \pm 30$ & -18 & $1300-1400 \mathrm{CE}$ \\
\hline 53828 & FT-11; $123 \mathrm{~cm}$ bs & nut endocarp & $664 \pm 29$ & -17 & $1300-1400 \mathrm{CE}$ \\
\hline 53826 & FT-11; $118 \mathrm{~cm}$ bs & nut endocarp & $641 \pm 34$ & -18 & $1300-1410 \mathrm{CE}$ \\
\hline
\end{tabular}

Source: Authors' data.

\section{Energetics}

Energetics estimates indicate that a likely number of people required to construct the ditch and rampart component of Fisi Tea lies in the range of 750 to 1000 people (Figure 8.6). It is possible that more people were used to speed up the construction process, but this would also have come with additional costs to maintain a larger work crew and greater supervision and management of the labour force. Similarly, a smaller number of people is unlikely due to the imminent threat of violence that likely necessitated the construction of Fisi Tea. The missionary George Vason observed 500 people performing fatongia to the Tu'i Kanokupolu Tuku'aho by working in the chief's fields (Orange 1840:140) and this is likely the lower limit to the size of the Fisi Tea workforce. While the presence of a palisade at Fisi Tea has not been confirmed, the nineteenth- 
century civil war-era fortification at Neiafu in Vava $u$ took three days to dig the earthworks and a day and a half to construct the palisade (Martin 1991:126), suggesting the Fisi Tea palisade may have taken 10-15 days to complete. A construction period of 30-50 days for the construction of Fisi Tea is likely given that traditional conflict in Tonga involved a period of time for chiefs to agree to an attack, and for different leaders to assemble, supply and coordinate their warriors.

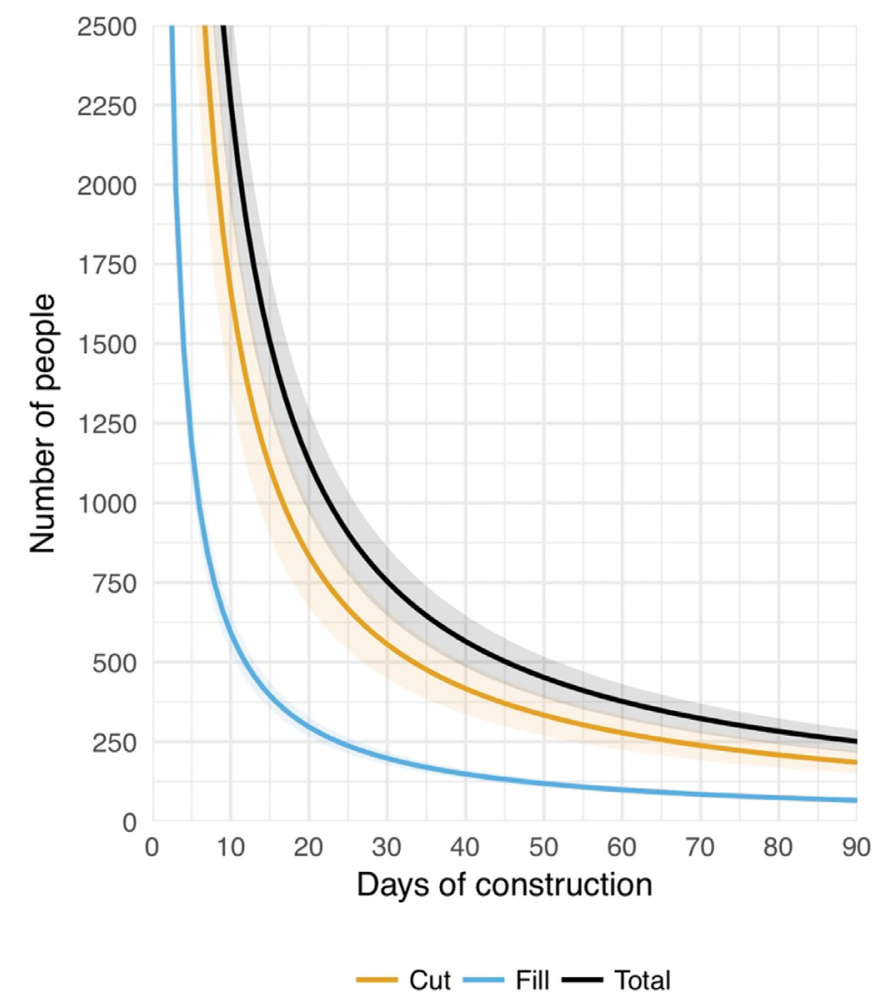

Figure 8.6. Energetics calculation for construction of Fisi Tea.

Uncertainties shown with shaded area surrounding the line.

Source: Phillip Parton, Geoffrey Clark and Christian Reepmeyer.

\section{Discussion}

Of the numerous potential functions that a large earthwork like Fisi Tea could have had, the single most important function was to protect the community and the eastern region of Tongatapu from a significant and imminent threat of violence. Of the criteria proposed by Keeley et al. (2007:79) and adopted by Parton et al. (2018) to define the defensive function of an earthwork, the $\mathrm{V}$-sectioned ditch backed by a rampart is the most diagnostic, having no other rational or practical function. Extraction of elevation profiles from Fisi Tea highlights a predominantly V-sectioned ditch (Figure 8.7). A water-carrying function for Fisi Tea can be ruled out as the V-sectioned ditch is inefficient at transporting water (Keeley et al. 2007:58). Most telling is that there is no standing source of fresh water in the vicinity of Fisi Tea (nor elsewhere on the limestone island) that could be directed by the Fisi Tea ditch toward Lapaha, the field systems and settlement; and the position of the rampart prevents overland flow of water into the ditch. In addition to a $\mathrm{V}$-sectioned ditch, probable, lookouts and a defended gate were likely important components of Fisi Tea. Placing warriors along an entire rampart wall is impractical and dilutes the strength of the defenders. To overcome this problem, lookouts are a predictable component of defensive walls and are placed at regular intervals to observe and communicate potential threats so that defenders can move directly to the point of attack. 


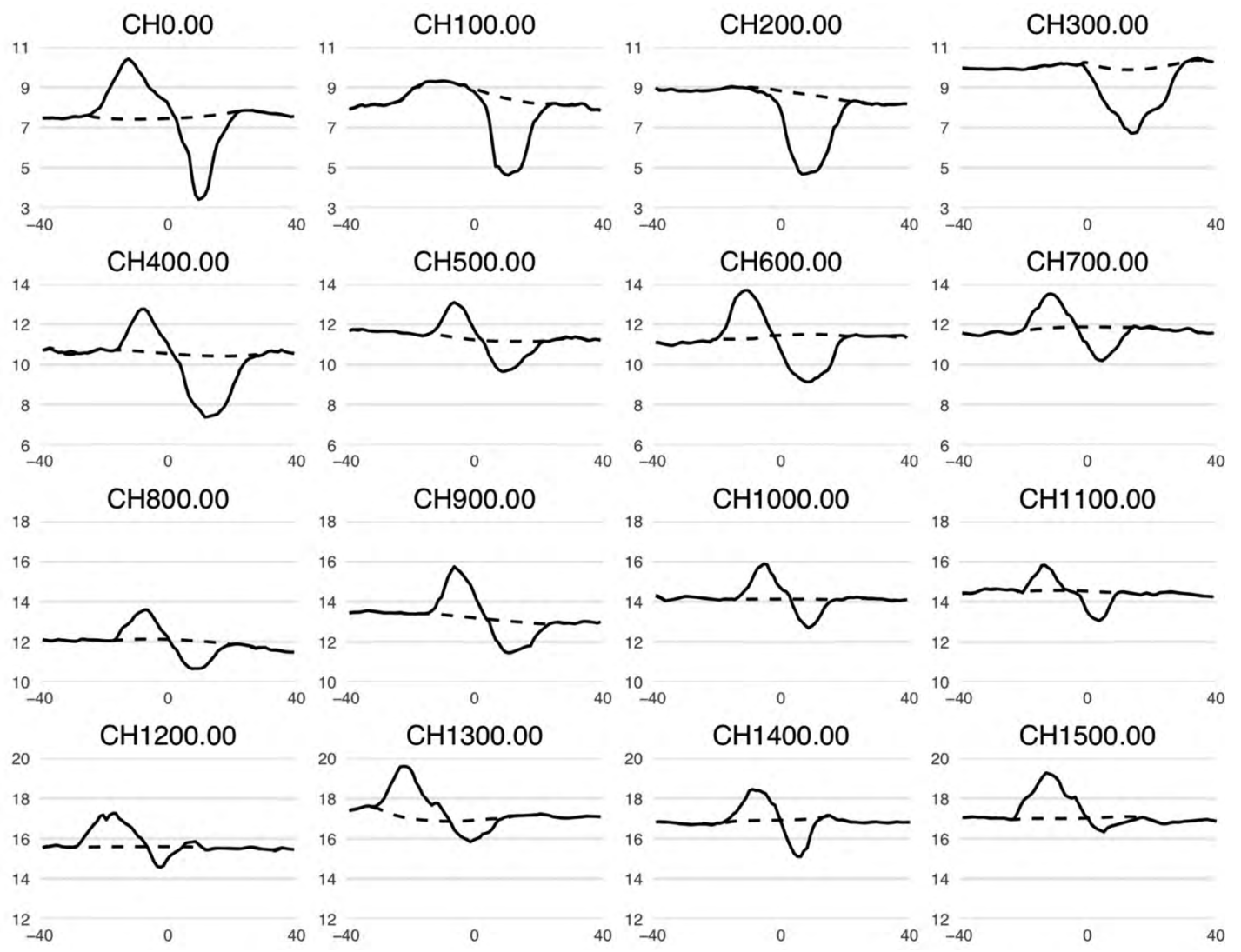

Figure 8.7. Selected elevation profiles extracted from the length of Fisi Tea.

Note the predominantly V-sectioned ditch. $\mathrm{CH} 100.00, \mathrm{CH} 200.00$ and $\mathrm{CH} 300.00$ are all situated in the destroyed section of the rampart. Interpolated original ground surface is shown with a dashed line.

Source: Phillip Parton, Geoffrey Clark and Christian Reepmeyer.

With an incoming force being monitored by a series of lookouts, attackers are forced to identify and direct their attacks towards weak points in the defensive wall, particularly gates, or try to bypass the defensive structure. Directing attacks towards gates has advantages for the attackers, but can also help defenders as the concentration of forces on a small section of wall mitigates any numerical superiority the attacking force may hold, buying time for extra defenders to arrive and mount a counterattack (Keeley 1996:56). Thus, gates become key locations that contain additional defensive features designed to strengthen the entrance. In Tonga, several visitors who described the civil war-era fortifications noted carefully designed gates (Martin 1991:79; Wilkes 1985:14, 22). At Fisi Tea, the only potential gate site is flanked by raised areas that may have supported defensive platform structures overlooking the entrance like those recorded in the nineteenth century. Vason described the effectiveness of gate elaborations in an attack on the Ma'ufanga sanctuary by the chief 'Ulukālala 'i Feletoa in 1799 CE, when their 'grand push at the entrance' was thwarted when 'the enemy stood immovable' as 'only a few of our troops could engage them' (Orange 1840:187). The gate then became an important position from which the defenders could counterattack and drive off the attackers.

The landscape immediately adjacent to Fisi Tea is characterised by a conspicuous absence of earth mounds, in an otherwise densely populated mound landscape (Figure 8.1) (Freeland et al. 2016). Despite mounds being largely unexplored, both archaeological and ethnographic sources indicate mounds were mainly built in the past 1000 years (Burley 1998:365; Davidson 1979), and functioned as house platforms, burial sites or a combination of both (Davidson 1969; Spenneman 1990). The important point is that the density of mounds at a location is likely 
to reflect the intensity of human occupation. Open areas or buffer zones can develop between two competing territories as a defensive measure to identify and repel attacks (LeBlanc 2006:443444), or arise passively to avoid possible conflict with neighbouring groups along a sensitive border. If mounds were built from c. 1000 years ago the buffer zone must pre-date the Fisi Tea construction and likely represents an undefended, or palisaded, territorial boundary.

At some point, additional defensive measures were necessary to protect the Lapaha hinterlands and the boundary was fortified with an earthwork. Fisi Tea's size, orientation and relationship with other defensive earthworks in Lapaha suggests an increase in the scale and intensity of territorial warfare. In Samoa, where Tongans were reputed to have built many fortifications, Krämer (1995:392) described the importance of territorial boundaries in traditional conflict:

Battles were in general fought at the border of both territories ... Only after a party had lost a battle, or at least after its retreat, did the other party penetrate into enemy territory.

Fisi Tea appears to be an ancient territorial boundary, as noted in a description of the tofía, or chiefly estate boundary between Lapaha (chiefly title 'Kalaniuvalu') and Tatakamotonga (chiefly title 'Tungî') made by Gifford (1929:172), which has the boundary 'following the road (or trench) [emphasis added] straight to the weather shore', highlighting the importance of the Fisi Tea ditch in the late nineteenth and early twentieth centuries. The boundary retains modern importance and despite slight alterations following cadastral survey in the 1960s, the modern chiefly boundaries are anchored to the bend point of Fisi Tea (Figure 8.1).

Two unresolved issues raised by Fisi Tea are the cause and timing of regional conflict within the Tongan state. Traditions mention several episodes of external warfare involving 'Uvea, Futuna and Samoa as well as conflict in other parts of Tonga (Ella 1899; Sand 2008; Thomas 2013). However, it was not until after European arrival that Tongatapu fell into civil war and many fortifications were built, leading to an assumption that almost all earthworks on Tongatapu were of recent age (Spennemann 1990:483). Prehistoric fortifications were certainly built earlier (Clark et al. 2018), but there is no detailed traditional history about many structures such as Fisi Tea, which, despite its imposing dimensions and location near the monumental core of Lapaha, was not recorded in previous archaeological studies of defensive earthworks (e.g. Spennemann 1990:483). One of the defining moments of the Tongan state in traditional history was the assassination of the $23 \mathrm{rd} \mathrm{Tu}^{\mathrm{i}} \mathrm{i}$ Tonga Takalaua, which had been preceded by the assassination of the 19th and 22nd Tu'i Tongas, indicating a period of significant political instability (Clark 2016).

Traditions contribute the important details that Takalaua's killers came from Ha'atalafale, a locality south of Lapaha, and the reason for regicide was the impost of labour to build a royal tomb during the yam planting season (Thomson 1968:301-302), or the alteration of traditional marriage arrangements (Thomas 2013:29). The immediate impact of Takalaua's death was a vigorous military campaign by his son, the 24 th Tu' $i$ Tonga Kau'ulufonuafekai, that extended through Tonga and into adjacent islands (Thomas 2013:29-30). Clearly, the geographic extent of warfare indicates the assassination involved more than two people and must have included a number of chiefs and long-running dissatisfaction with the Tu'i Tonga system. This is shown by the creation, after Kau'ulufonuafekai's return to Tongatapu, of a new chiefly lineage known as the Tu'i Ha'atakalaua. The lineage had a focus on administrative and practical governance, which distanced the Tu'i Tonga from unpopular decisions that had previously led to political assassination and conflict while maintaining, at least initially, the paramount's status and influence. The creation of a diarchy at Lapaha was manifested spatially by the Tu'i Ha'atakalaua line occupying the reclaimed land in front of the old shoreline, while the Tu'i Tonga held the landward area. The division led to the term Kaubala 'uta to refer to the Tu'i Tonga's followers and Kauhalalalo to describe people under junior chiefly titles (Bott 1982:156). We suggest that Fisi Tea represents another political axis that is not recorded in traditional history, with the fortified 
boundary between Lapaha and the rest of Tongatapu built to defend Lapaha and parts of the greater Hahake region against a coalition of chiefs based elsewhere on Tongatapu who organised or supported the assassination of Takalaua (and previous Tu'i Tonga).

At Fisi Tea, a secondary function in building the earthwork was likely the construction of large and deep ditches close to Lapaha. The size of the ditches in this area matches those of Olotele and Hautama/Ha'amea, which surround the political core of monumental architecture and represents what Trigger (1990:124) calls 'conspicuous consumption'. Building the defences closest to Lapaha at a monumental scale communicates the power and prestige of the polity to both internal and external groups (Rapoport 2006; Trigger 1990). Successfully repelling enemy attacks would also increase the prestige and symbolic value of the defence (Keeley 1996:57). Ultimately, 'fortifications are most symbolically useful when they are militarily functional' (Keeley et al. 2007:81), and advances in military technology can quickly make the secondary functions of the defence a liability - as seen in fifteenth-century Europe, where impressive city walls were destroyed following the introduction of the cannon (de la Croix 1972:39-41; Parker 2000).

As the weakest points of the overall construction of the wall and focal points of enemy attack, gates receive elaborations to prevent attackers penetrating the territory. In peacetime, leaders quickly realised that gates continue to restrict the movement of people and goods through the region and with small alterations, can be redesigned or adapted to collect customs, taxes and information as people are funnelled through them (Connah 2000:41; Richmond 2013:247-248; Russell 2013; Turner 1970). McKern (1929:95) identified a single gate from the south into Olotele and survey analysis suggests a second gate in the hinterland. In contrast, an approximately $350 \mathrm{~m}$ portion of the Hu'atolitoli linear fortification (Number 54 in Parton et al. 2018:Table 1) visited in the field has a series of major and minor gates at 70-80 m intervals that would permit the regular movement of people and goods through the defence. The small number of major gates and absence of minor gates on Fisi Tea indicate that control over the movement of goods and people entering the eastern region remained important long after the initial requirement for the construction of Fisi Tea had passed, with supporting evidence in local traditions and historical accounts. First, Lapaha traditions state that visitors to Olotele were required to wait by the gate on the Tatakamotonga side before being escorted into the compound and failure to wait for an escort resulted in death. Second, in 1799 CE while waging war after the assassination of Tu' $\mathrm{i}$ Kanokupolu Tuku'aho, the chief Vaha'i was advancing from Hihifo to the stronghold of Poha located in north-east Hahake. The army of Vaha' $i$ was only allowed to pass through the area after hiding their weapons and pretending to be on a visit to relatives (Collocott 1928:91).

Large defensive earthworks like Fisi Tea differ from other types of monumental architecture built in Tonga, and consequently illuminate different aspects of social organisation. Where the elite chiefly class were able to levy labour for stone-faced tombs, sporting venues and ocean-going vessels through fatongia (Burley 1993), the construction of defensive earthworks by a group as a response to an imminent threat of intense violence suggests that labour procurement was through cooperation rather than coercion (i.e. Roscoe 2012:75).

Energetics calculations provide an empirical estimate of community participation in the Fisi Tea earthwork. The most recent estimates of prehistoric population size of Tongatapu are approximately 18000 people (Burley 2007:185). Using mound number and land area of the total eastern region enclosed by Fisi Tea as a proxy for population distribution, the Hahake region would have been home to approximately 4500 people. With $750-1000$ people working on the construction of Fisi Tea over a period of 30-50 days, a significant proportion of the population would have had a direct role in the construction and many others would have been involved indirectly in supporting the work. 
Managing the large number of people present during construction requires a level of managerial expertise to coordinate their movements and activities, and to ensure construction is completed on time and to specification (Webster et al. 2007). Additional interrelated tasks such as vegetation clearing, surveying the route and preparing construction surfaces all contribute to the construction of Fisi Tea. The standardised rampart construction observed in the survey analysis indicates that the designers had clear ideas of how Fisi Tea should look and they were able to communicate the plan to the workers with remarkable precision, and when problems were encountered adjustments were devised to solve them. The regular placement of probable lookouts and the incorporation of the adjacent buffer zones into the overall defences shows that the architects of Fisi Tea had strong strategic and tactical knowledge, which might indicate a long history of conflict at territory borders.

High community participation combined with project supervision by elites in the construction of defensive walls is recorded historically in Tonga and in other parts of the world. The Aurelian walls of Rome were constructed by community level collegia with oversight and coordination coming directly from Emperor Aurelian (Richmond 2013:244). In Tonga, the chief 'Ulukālala 'i Feletoa (Mariner's 'Finow', in Martin 1991) was actively involved in fort-building by coordinating work parties and procuring the necessary materials, and while the workers were performing these activities, 'Finow and his principal chiefs remained to lay out the plan' (Martin 1991:126).

\section{Conclusion}

This study of the Fisi Tea earthwork has demonstrated the power of lidar data to examine the archaeological landscape at a level well beyond its more common use in site prospection. By employing a high-resolution spatial analysis incorporating multiple earthwork morphology variables, and associated error estimates, the lidar data informed our knowledge of defensive features. These included subtle changes to the landscape that challenged the builders of Fisi Tea and the innovative solutions they used to overcome construction problems. The methodology can be applied to other defensive earthworks in Tonga, and extended to a variety of prehistoric sites such as earth mounds to examine the size, distribution and density of built structures throughout the landscape (e.g. Freeland et al. 2016).

Fisi Tea shows the growing capacity of the Tongan state to respond to significant threats to the government of the Tu'i Tonga, potentially during a time of major political upheaval within the Tonga Group. The landscape surrounding Fisi Tea is characterised by a marked absence of residential structures in the vicinity of the earthwork, suggesting that Fisi Tea was located on a pre-existing boundary between groups that may have been palisaded before the earthwork was built. In addition to earlier fortifications in the Lapaha area (Lapaha Kolotau and Olotele), Fisi Tea supports a view that political centralisation in Tonga was contested (Clark et al. 2018:416), and the monumental core of the paramount Tu' $i$ Tonga was exposed to the threat of serial conflict. On Tongatapu, many of the traditional land boundaries associated with chiefly titles traversed the island from one coastline to another (e.g. Gifford 1929:Figure 4). During episodes of conflict these boundaries were probably controlled and, at times, defended by linear earthworks like Fisi Tea that defined the political territory of a social group. Following hostilities a new kind of chiefly structure and landscape emerged that spread Tongan influence to many parts of the Pacific, demonstrating the role of warfare in forging strong political systems. It is notable that warfare within Tongatapu prior to the nineteenth century is poorly attested in traditional history and lidar analysis in conjunction with archaeological excavation of defensive systems can provide insight to the 'hidden' history of conflict in Tonga. 


\section{References}

Abrams, E.M. 1989. Architecture and energy: An evolutionary perspective. Archaeological Method and Theory 1:47-87.

Anderson, H. 2011. Tongatapu and Lifuka Islands, topographic and bathymetric LIDAR, data capture project. Final Project Report 18924A. AAM Group, Melbourne.

Arkush, E. and C. Stanish 2005. Interpreting conflict in the ancient Andes. Current Anthropology 46:3-28. doi.org/10.1086/425660.

Beaglehole, J.C. (ed.) 1967. The journals of Captain James Cook on his voyages of discovery. Volume III: The voyage of the Resolution and Discovery 1776-1780. Cambridge University Press, London.

Bell, M., P.J. Fowler and S.W. Hillson 1996. The experimental earthworks project: 1960-1992. Research Report 100. Council for British Archaeology, York.

Blitz, J.H. and P. Livingood 2004. Sociopolitical implications of Mississippian mound volume. American Antiquity 69:291-301.

Bott, E. 1982. Tongan society at the time of Cook's visit: Discussions with Her Majesty Queen Sälote Tupou. Memoir No. 44. The Polynesian Society, Wellington.

Burley, D.V. 1993. Chiefly prerogatives over critical resources: Archaeology, oral traditions and symbolic landscapes in the Ha'apai Islands, Kingdom of Tonga. In R. Jamieson, S. Abonyi and N. Mirau (eds), Culture and environment: A fragile co-existence, pp. 437-443. University of Calgary, Calgary.

Burley, D.V. 1998. Tongan archaeology and the Tongan past, 2850-150 B.P. Journal of World Prehistory 12:337-392.

Burley, D.V. 2007. Archaeological demography and population growth in the Kingdom of Tonga. In P.V. Kirch and J.-L. Rallu (eds), The growth and collapse of Pacific island societies, pp. 177-202. University of Hawai'i Press, Honolulu. doi.org/10.1515/9780824864767-013.

Chase, A.F., D.Z. Chase, C.T. Fisher, S.J. Leisz and J.F. Weishampel 2012. Geospatial revolution and remote sensing LiDAR in Mesoamerican archaeology. Proceedings of the National Academy of Sciences USA 109:12916-12921. doi.org/10.1073/pnas.1205198109.

Clark, G. 2016. Chiefly tombs, lineage history, and the ancient Tongan state. Journal of Island and Coastal Archaeology 11(3):326-343. doi.org/10.1080/15564894.2015.1098754.

Clark, G. and C. Reepmeyer 2014. Stone architecture, monumentality and the rise of the early Tongan chiefdom. Antiquity 88:1244-1260. doi.org/10.1017/s0003598x00115431.

Clark, G. and H. Martinsson-Wallin 2007. Monumental architecture in West Polynesia: Origins, chiefs and archaeological approaches. Archaeology of Oceania Supplement 42:28-40. doi. org/10.1002/j.1834-4453.2007.tb00006.x.

Clark, G., D. Burley and T. Murray 2008. Monumentality and the development of the Tongan maritime chiefdom. Antiquity 82:994-1008. doi.org/10.1017/s0003598x00097738.

Clark, G., C. Reepmeyer and N. Melekiola 2016. The rapid emergence of the archaic Tongan state: The royal tomb of Paepaeotelea. Antiquity 90:1038-1053. doi.org/10.15184/aqy.2016.114.

Clark, G., P. Parton, C. Reepmeyer, N. Melekiola and D. Burley 2018. Conflict and state development in ancient Tonga: The Lapaha earth fort. Journal of Island and Coastal Archaeology 13(3):405-419. doi.org/10.1080/15564894.2017.1337658.

Collocott, E.E.V. 1928. Tales and poems of Tonga. Bernice P. Bishop Museum Bulletin 46. Bernice P. Bishop Museum, Honolulu. 
Congalton, R. and K. Green 2009. Assessing the accuracy of remotely sensed data: Principles and practices. 2nd edition. CRC Press, Boca Raton. doi.org/10.1201/9781420055139.

Connah, G. 2000. Contained communities in tropical Africa. In J. Tracey (ed.), City walls: The urban enciente in global perspective, pp. 19-45. Cambridge University Press, Cambridge.

Davidson, J.M. 1969. Archaeological excavations in two burial mounds at 'Atele, Tongatapu. Records of the Auckland Institute and Museum 6:251-286.

Davidson, J.M. 1979. Samoa and Tonga. In J.D. Jennings (ed.), The prehistory of Polynesia, pp. 82-109. Harvard University Press, Harvard and Cambridge.

de la Croix, H. 1972. Military considerations in city planning: Fortifications. George Braziller, New York.

Ella, S. 1899. The war of Tonga and Samoa and the origin of the name Malietoa. Journal of the Polynesian Society 8(4):231-234.

Erasmus, C.J. 1965. Monument building: Some field experiments. Southwestern Journal of Anthropology 21:277-301. doi.org/10.1086/soutjanth.21.4.3629433.

Fernandez-Diaz, J.C., W.E. Carter, R.L. Shrestha and C.L. Glennie 2014. Now you see it ... Now you don't: Understanding airborne mapping LiDAR collection and data product generation for archaeological research in Mesoamerica. Remote Sensing 6:9951-10001. doi.org/10.3390/rs6109951.

Fox, A. 1976. Prehistoric Maori fortifications in the North Island of New Zealand. Longman Paul Limited, Auckland.

Freeland, T., B. Heung, D.V. Burley, G. Clark and A. Knudby 2016. Automated feature extraction for prospection and analysis of monumental earthworks from aerial LiDAR in the Kingdom of Tonga. Journal of Archaeological Science. 69:64-74. doi.org/10.1016/j.jas.2016.04.011.

Ghilani, C. 2010. Adjustment computations: Spatial data analysis. 5th edition. Wiley, Hoboken.

Gibbs, H. 1976. Soils of Tongatapu, Tonga. New Zealand Soil Survey Report 35. Department of Scientific and Industrial Research, Wellington.

Gifford, E.W. 1929. Tongan society. Bernice P. Bishop Museum Bulletin 61. Bernice P. Bishop Museum, Honolulu.

Hannon, N., D.J. Rohl and L. Wilson 2017. The Antonine Wall's distance-slabs: LiDAR as metric survey. Journal of Roman Archaeology 30:447-468. doi.org/10.1017/s1047759400074201.

Hartzell, P.J., P.J. Gadomski, C.L. Glennie, D.C. Finnegan and J.S. Deems 2015. Rigorous error propagation for terrestrial laser scanning with application to snow volume uncertainty. Journal of Glaciology 61:1147-1158. doi.org/10.3189/2015jog15j031.

Hodgson, M.E. and P. Bresnahan 2004. Accuracy of airborne Lidar-derived elevation. Photogrammetric engineering and remote sensing 70:331-339. doi.org/10.14358/pers.70.3.331.

Keeley, L.H. 1996. War before civilization: The myth of the peaceful savage. Oxford University Press, New York.

Keeley, L.H., M. Fontana and R. Quick 2007. Baffles and bastions: The universal features of fortifications. Journal of Archaeological Research 15(1):55-95. doi.org/10.1007/s10814-006-9009-0.

Kim, N.C. 2013. Lasting monuments and durable institutions: Labor, urbanism, and statehood in Northern Vietnam and beyond. Journal of Archaeological Research 21:217-267. doi.org/10.1007/ s10814-012-9064-7. 
Kolb, M.J. 1997. Labor mobilization, ethnohistory, and the archaeology of community in Hawai' $\mathrm{i}$. Journal of Archaeological Method and Theory 4:265-285. doi.org/10.1007/bf02428064.

Krämer, A. 1995. The Samoa Islands. Volume II: Material culture. Translated by Dr Theodore Verhaaren. University of Hawai'i Press, Honolulu.

Lātūkefu, S. 1980. The definition of authentic Oceanic cultures with particular reference to Tongan culture. Pacific Studies 4:60-81.

LeBlanc, S. 2006. Warfare and the development of social complexity. In E. Arkush and M. Allen (eds), The archaeology of warfare: Prehistories of raiding and conquest, pp. 437-468. University Press of Florida, Florida.

Lustig, T., S. Klassen, D. Evans, R. French and I. Mo 2018. Evidence for the breakdown of an Angkorian hydraulic system, and its historical implications for understanding the Khmer Empire. Journal of Archaeological Science: Reports 17:195-211. doi.org/10.1016/j.jasrep.2017.11.014.

Martin, J. 1991. Tonga islands: William Mariner's account. 5th edition. Vava'u Press, Nuku'alofa.

McKern, W.C. 1929. Archaeology of Tonga. Bernice P. Bishop Museum Bulletin 60. Bernice P. Bishop Museum, Honolulu.

Opitz, R.S., K. Ryzewski, J.F. Cherry and B. Moloney 2015. Using airborne LiDAR survey to explore historic-era archaeological landscapes of Montserrat in the Eastern Caribbean. Journal of Field Archaeology 40(5):523-541. doi.org/10.1179/2042458215y.0000000016.

Orange, J. 1840. Life of the late George Vason of Nottingham. Henry Mozley and Sons, Derby.

Ortmann, A.L. and T.R. Kidder 2013. Building Mound A at Poverty Point, Louisiana: Monumental public architecture, ritual practice, and implications for hunter-gatherer complexity. Geoarchaeology 28:66-86. doi.org/10.1002/gea.21430.

Parker, G. 2000. The artillery fortress as an engine of European overseas expansion, 1480-1750. In J. Tracey (ed.), City walls: The urban enciente in global perspective, pp. 386-418. Cambridge University Press, Cambridge.

Parton, P., G. Clark, C. Reepmeyer and D. Burley 2018. The field of war: LiDAR identification of earthwork defences on Tongatapu Island, Kingdom of Tonga. Journal of Pacific Archaeology 9(1):11-24.

Pickett, J., J.S. Schreck, R. Holod, Y. Rassamakin, O. Halenko and W. Wood 2016. Architectural energetics for tumuli construction: The case of the medieval Chungul Kurgan on the Eurasian steppe. Journal of Archaeological Science 75:101-114. doi.org/10.1016/j.jas.2016.09.006.

Rabone, S. 1845. Vocabulary of the Tonga language. Wesleyan Mission Press, Vava'u.

Rapoport, A. 2006. Archaeology and environment-behavior studies. In W. Ashmore, M. Dobres, S. Nelson and A. Rosen (eds), Integrating the diversity of twenty-first-century anthropology: The life and intellectual legacies of Susan Kent, pp. 59-70. American Anthropological Association, Washington.

Richmond, I. 2013. The city wall of Imperial Rome: An account of its architectural development from Aurelian to Narses. Westholme Publishing, Yardley.

Roscoe, P. 2012. War, collective action, and the 'evolution' of human polities. In D.M. Carballo (ed.), Cooperation and collective action: Archaeological perspectives, pp. 70-96. University Press of Colorado, Boulder.

Rosenswig, R.M. and R. Burger 2012. Considering early New World monumentality. In R. Burger (ed.), Early New World monumentality, pp. 3-22. University Press of Florida. Gainesville. doi.org/10.5744/ florida/9780813038087.003.0001. 
Russell, B.W. 2013. Fortress Mayapan: Defensive features and secondary functions of a postclassic Maya fortification. Ancient Mesoamerica 24:275-294. doi.org/10.1017/s0956536113000217.

Sand, C. 2008. Prehistoric maritime empires in the Pacific: Ga'asialili ('Elili) and the establishment of a Tongan colony on 'Uvea (Wallis, Western Polynesia). In A. Di Piazza, E. Pearthree and C. Sand (eds), At the heart of ancient societies: French contributions to Pacific archaeology, pp. 73-105. Cahiers de l'Archeologie en Nouvelle Caledonie, Noumea.

Scherer, A.K. and C. Golden 2006. Tecolote, Guatemala: Archaeological evidence for a fortified Late Classic Maya political border. Journal of Field Archaeology 34(3):285-305. doi.org/10.1179/0093469 09791070907.

Sherwood, S.C. and T.R. Kidder 2011. The DaVincis of dirt: Geoarchaeological perspectives on Native American mound building in the Mississippi River basin. Journal of Anthropological Archaeology 30:69-87. doi.org/10.1016/j.jaa.2010.11.001.

Spenneman, D.H.R. 1990. 'ata 'a Tonga mo 'ata 'o Tonga: Early and later prehistory of the Tongan Islands. Volumes I and II. Unpublished PhD thesis. The Australian National University, Canberra.

Thomas, J. 2013. A history of Tonga. Bible Society in Korea, Seoul.

Thomson, B. 1968. The diversions of a Prime Minister. Dawsons of Pall Mall, London.

Trigger, B.G. 1990. Monumental architecture: A thermodynamic explanation of symbolic behaviour. World Archaeology 22:119-132. doi.org/10.1080/00438243.1990.9980135.

Turner, H. 1970. Town defences in England and Wales: An architectural and documentary study, AD 9001500. John Baker, London.

Webster, D., T. Murtha, K.D. Straight, J. Silverstein, H. Martinez, R.E. Terry and R. Burnett 2007. The Great Tikal earthwork revisited. Journal of Field Archaeology 32:41-64. doi.org/10.1179/0093 46907791071700 .

Webster, D., J. Silverstein, T. Murtha, H. Martinez and K. Straight 2008. Political ecology of the Tikal earthworks: A Maya Altepetl boundary? Urbanism in Mesoamerica 1:349-376.

Wilkes, C. 1985. United States Exploring Expedition. Volume III: Tongataboo, Feejee group, Honolulu. Fiji Museum, Suva.

Wilson, J. 1799. A missionary voyage to the Southern Pacific Ocean, performed in the years 1796, 1796, 1798, in the ship Duff, commanded by Captain James Wilson. Frederick A. Praeger, New York. 
This text is taken from Archaeological Perspectives on Conflict and Warfare in Australia and the Pacific, edited by Geoffrey Clark and Mirani Litster, published 2022 by ANU Press, The Australian National University, Canberra, Australia.

doi.org/10.22459/TA54.2021.08 